\title{
The Impact of the June 4th Massacre on the pro- Democracy Movement
}

Jean-Philippe Béja and Merle Goldman

\section{(2) OpenEdition}

1 Journals

Electronic version

URL: http://journals.openedition.org/chinaperspectives/4801

DOI: 10.4000/chinaperspectives.4801

ISSN: 1996-4617

Publisher

Centre d'étude français sur la Chine contemporaine

\section{Printed version}

Date of publication: 1 June 2009

Number of pages: $18-28$

ISSN: 2070-3449

\section{Electronic reference}

Jean-Philippe Béja and Merle Goldman, «The Impact of the June 4th Massacre on the pro-Democracy Movement », China Perspectives [Online], 2009/2 | 2009, Online since 01 June 2011, connection on 28 October 2019. URL : http://journals.openedition.org/chinaperspectives/4801 ; DOI : 10.4000/

chinaperspectives.4801

This text was automatically generated on 28 October 2019 .

(C) All rights reserved 


\title{
The Impact of the June 4 th Massacre on the pro-Democracy Movement
}

\author{
Jean-Philippe Béja and Merle Goldman
}

\section{ABSTRACTS}

The Chinese pro-democracy movement crushed by the People's Liberation Army on 4 June 1989 was preceded by many protests by intellectuals. The crackdown deprived the democrats of their protectors in the Party, and forced them to change strategies. Unable to organise large-scale demonstrations, dissidents launched petitions demanding respect for human rights and reversal of the official verdict on June 4th. They were joined by the Tiananmen Mothers, who became a new force in the pro-democracy movement. Yet, China's democracy activists remain largely isolated from the rest of society.

\section{AUTHORS}

JEAN-PHILIPPE BÉJA

Researcher Director at CNRS/CERI - Sciences Po and Researcher at the CEFC Hong Kong MERLE GOLDMAN

Professor Emerita of History at Boston University. 